\title{
Evaluating the predictive accuracy of microloan officers' subjective judgment
}

Baklouti, Ibtissem $\$

Faculty of Economic Sciences and Management of Sfax, Tunisia (bakloutiibtissem@yahoo.fr)

Baccar, Amel

Faculty of Economic Sciences and Management of Sfax, Tunisia (amelbaccar@yahoo.fr)

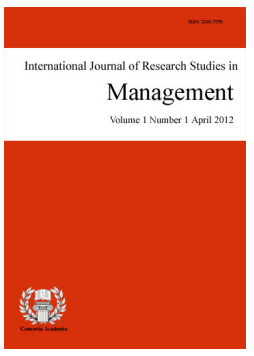

ISSN: $2243-7770$ Online ISSN: 2243-7789

OPEN ACCESS

\section{Abstract}

The peculiarity in lending methodology in Microfinance institution characterized by unchallenged dominance of the loan officers in the decision-making prompted us to investigate the predictive accuracy of their subjective judgement. In addition, we investigate if the accuracy of this information depends on the strength of lenders-borrowers relationship. The objective of this paper is to understand the loan officer behaviour in default prediction task. Using credit file data from Tunisian Microfinance bank, we have found evidence that subjective judgment of loan officers has statistically significant predictive capability of default risk. In addition, our results suggest that novice loan officers have incorrect prediction of future default events because they are prone to different behavioral biases. Novice loan officers may overweight any information that is consistent with their existing beliefs and overestimate the precision of their own private information. However, through learning experienced loan officers have less behavior bias and more accurate feeling allowing them to make an accurate default prediction. To make correct decision in relationship lending approach, credit committee can rely on subjective judgment of experienced loan officers mainly when the latter judged the creditworthiness of frequent borrowers. As soft information is not easily and accurately transferable, Microfinance institutions have more interest to retain their experienced loan officers than their borrowers.

Keywords: subjective judgment; loan officer; predictive accuracy; expertise; microfinance institution 


\section{Evaluating the predictive accuracy of microloan officers' subjective judgment}

\section{Introduction}

Traditionally, the first forecasting method in granting credit decision is relationship lending approach. In this approach, granting decision is based on subjective judgment of loan officers drawing from the experience of previous lending decisions. Subjective judgment represents soft qualitative information obtaining during the close ties and interaction with customers. It can provide a forward view by recognising factors that cannot be reflected in a purely empirical grade, such as project viability or market conditions. The theoretical literature in microfinance has long emphasized that relationship lending approach is particularly well-suited for Microfinance institutions (MFI), which assess opaque SMEs (small and medium enterprises) that do not have audited financial statements or sufficient pledgeable collateral (Petersen \& Rajan, 1995; Schrader, 2009; Stein, 2002). The loan officers in MFI are trained to collect and make judgments about information on entrepreneur's personality and entrepreneur's project. This would typically involve a face-to-face meeting with each applicant where the loan officer - intentionally or unintentionally - forms judgments about its creditworthiness after interviewing him. Furthermore, loan officers should consider information about business conditions such as forecasts about market, economic growth, and additional macro-economic factors. Those indications are essential in order to get a feeling about the management's ability to handle changes in the environment.

Loan officers in relationship technique produce and interpret soft information through interpersonal interactions often on the basis of limited information and cognitive capacity. Cognitive factor and emotional factor are integral components of soft information. Hence, this information represents a critical input to the lending decision (Scott, 2006). As noted by Schreiner (2004), no one knows how important loan officers "sixth sense" is. Two assumptions can be advanced. The first assumption is that loan officer acts like economic agents who may be subject to multiple biases that affect their judgment. Many authors, for instance, have considered intuition and emotion as a primary source of error in judgment formation. As noted by Somerville and Taffler (1995), research in psychology suggests that human judgment may be prone to bias. This means that intuitional, emotional and behavioral factors decrease loan officers' assessment of borrower's creditworthiness. The second assumption is that loan officer should provide a more complete profile for credit decisions due to his capacity to collect and interpret in a consistent way all soft exclusive information. This means that intuitional, emotional and behavioural factors enhance loan officers' assessment of borrower's creditworthiness. In this case, loan officer is assumed be fully rational agent, making decisions on the base of real, although noisy and not verifiable information concerning the borrower creditworthiness.

Although the role of subjective judgment in prediction accuracy is controversial in relationship lending approach, there is a wide consensus that this soft information increases classification accuracy in transactional lending approach. Indeed, credit scoring model can capture the behaviour of loan officer -even if it is a bias- and improve classification accuracy through learning. For example, Cornée et al. (2009) followed the methodology of previous studies that have investigated the role of loan officer's subjective judgment in credit prevision accuracy for traditional banks (Grunert, Norden, \& Weber, 2005; Lehmann, 2003) and concluded that loan officer's subjective assessment in MFI usually increases credit classification accuracy and cannot be neglected. This result leads us to investigate the relation between the quality of loan officers' subjective judgment and the learning through lenders-borrowers relationship.

Few studies have investigated the role of soft factors in relationship lending in MFI. The peculiarity in lending methodology in MFI characterized by unchallenged dominance of the loan officers in the decision-making prompted us to investigate the predictive accuracy of soft information in relationship lending approach. In addition, we investigate if the quality of this information depends on the strength of lenders-borrowers relationship. The objective of this paper is to understand the behaviour of loan officer in 
default prediction task. Our paper represents the first study that try to give as an understanding about loan officer's behavior in Tunisian Microfinance institution. The remaining of this article is as follows: A body of psychological research on the predictive accuracy of human judgement and its relation with the strength of lender-borrower relationship is developed in section 2. Section 3 defines the data and describes the methodology. The results are presented in Section 4 and Section 5 concludes.

\section{Predictive accuracy of subjective judgment in relationship lending approach: A Psychological}

\section{Perspective}

\subsection{Loan officers'subjective judgment: Noise or New information}

Many psychological studies maintain that human judgement frequently fail to interpret and integrate new information and others studies argue that using human judgment is very beneficial. Using human in credit granting decision is controversial. Two areas can be presented.

In the first area, people regard subjective judgment as unreliable because the process of subjective judgment may be influenced by affects such as fear, regret, overconfidence and optimism. In behavioral finance, researchers have documented that subjective judgment of forecasters are subject to many sorts of judgmental heuristics and human biases that can lead to severe and systematic errors (Hogarth, 1980; Hogarth \& Makridakis, 1981; Kahneman \& Tversky, 1979). Daniel Kahneman and the Amos Tversky showed that intuition of average people is subject to errors. Bonabeau (2003) argued that intuition and emotion of man may be a primary source of error in judgment formation. Peterson and Beach (1967) argued that "man as an intuitive statistician" is liable to incur significant biases in the use of information. Some studies found that statistical models outperform experts in judgmental prediction tasks (Hogarth \& Makridakis, 1981) and concluded that judgement was characterized as being associated with systematic biases and large errors.

Somerville and Taffler (1995) compared the forecasts accuracy of statistical models (linear discriminant analysis and logit analysis) and the forecasts accuracy of human judgmental-based models ${ }^{1}$ in the case of banks' country risk assessment. They found that bankers' judgment is biased toward an adverse view of the creditworthiness (over pessimism about the creditworthiness of less developed countries) and classification performance is lower than that of formal statistical models. In the same context, Taffler and Abassi (1984) founded that bankers may be influence by "sentiment" about particular countries rather than by economic fundamentals. Many recent social-psychological and behavioral research studies on decisions related to risk in bank have acknowledged the importance of non-rational behavioral or emotional factors.

Loan officers in the loan-approval decisions are engaged in "emotional labor" and their risk assessments can be affected by the stereotypes they form about the borrowers' entrepreneurial capacity and trustworthiness. They can for example have a "feelings of sympathy for defaulters" (Dixon, Ritchie, \& Siwale, 2007). The findings from McNamara and Bromiley's (1997) study of loan officer's behaviour working for U.S commercial banks showed that cognitive process followed by loan officers when they make judgment on risk improves the likelihood of risk assessment errors. This result indicated the presence of loan officer's cognitive biases leading to risk-rating errors. For example, "a fads-and-fashions effect can influence loan officers who may prefer to lend to firms in exciting or innovative industries even if industry performance indicators suggest otherwise" (McNamara \& Bromiley, 1997, p. 1070).

Hertzberg, Liberti, and Paravisini (2010) showed empirically that loan officers might have an information bias and strong risk aversion. Using data from a large multinational U.S. bank operating in Argentina, they concluded that loan officer, who is responsible for forecasting the borrower's creditworthiness and reporting

1 Somerville and Taffler (1995) have used country credit ratings published regularly in the Institutional Investor since 1979, as measures of banker judgment. 
information about them, reveals negative information about their borrowers' repayment prospects because of the threat of job rotation. This occurs because, according to loan officer, it seems to be better for his career to self-revealing bad news instead of having bad information revealed by a successor. Some papers have examined the effect of lender's gender on perceptions of borrowers' creditworthiness (Barasinska, 2009; Carter, Shaw, Lam, \& Wilson, 2007; Ravina, 2008). These studies concluded that as male loan officers reveal higher risk propensity and/or overconfidence, the predictive accuracy of male loan officers will be lower than predictive accuracy of female loan officers. Female loan officers have a tendency to assess borrowers' creditworthiness more cautiously and reach better credit decisions.

The ability of microcredit officers to evaluate the probability that the loan will be repaid was recently criticized, mainly after the several hardships and the important crisis which shaken the microfinance sector. For example, the recent crisis of 2010 in Andhra Pradesh, one of the microfinance crises that the sector does not want to remember, has shown that loan officers, blinded by the high level of competition, granted loans to over-indebted clients, who are not in reality creditworthy. In granting decision, the loan officers could be tempted to follow their subjective preferences or judgment, possibly discriminatory judgment, rather the MFI's best interests. Different authors have investigated evidence of discrimination of credit officers against a group of the target population in microfinance market.

In the US market, Cavalluzzo and Cavalluzzo (1998) found that businesses held by Hispanics and blacks face higher loan denial rates than those owned by whites. Blanchflower, Levine, and Zimmerman (2003) concluded that the racial disparity in credit availability is likely caused by racial discrimination in the small-business credit market. They found that black-owned small businesses are about twice as likely to be denied credit as white-owned ones, holding all other factors constant. Blanchard, Zhao, and Yinger (2008) and Cavalluzzo and Wolken (2005) confirmed those results. Discrimination in loan granting also exists in developing countries. Storey (2004) tested for the presence of racial and gender discrimination of loan officer in the granting decision and concluded the possible presence of discrimination. In particular, he showed that, in Trinidad and Tobago, applications from African small-business owners are more likely to be denied than others. Recently, the subjectivity and judgmental biases of credit officers in credit granting are investigated by Agier and Szafarz (2012). Their paper offers the first empirical estimation of the impact of loan officers' subjectivity on microcredit granting. Using database from VivaCred, a Brazilian microfinance institution, Agier and Szafarz (2012) observed from descriptive data that women entrepreneurs receive smaller loans than their male counterparts, all other things being equal. The result of their estimations showed that the unfair gender discrimination in loan size is almost exclusively attributable to the loan officers' misjudgement. In particular, the gap unjustified by pure credit-scoring characteristics $(34.7 \%$ ) can be divided into $27.3 \%$ of subjective bias created by loan officers and $7.4 \%$ of subjective bias created credit committee.

While behavioural finance theory assumes the bounded rationality as a model that overcomes some of the limitations of the rational-agent models in economic literature, another growing body of research shows that intuition is not necessarily biased and can improve decision making under the constraint of bounded rationality, playing therefore a role in the range of economic theories. In this second area, intuition may permit heuristics to be rapidly deployed and likely arises through tacit knowledge ${ }^{2}$ developed during learning (Harteis \& Gruber, 2008). Tacit knowledge or "silent knowledge" concerns interpersonal relationships skills and includes the use of intuition, feelings and emotional intelligence that are not so easily expressed but may be demonstrated as skills and competences.

Several empirical evidences showed that a well-structured judgmental process can improve forecast accuracy and can consistently outperform a statistical model (Edmundson, Lawrence, \& O'Connor, 1988; Lawrence, Edmundson, \& O’Connor, 1985; McCarthy, Davis, Golicic, \& Mentzer, 2006; Turner, 1990; Wolfe \&

\footnotetext{
2 Tacit knowledge is information about the borrower that cannot be directly verified by anyone else than the loan officer. In lending, tacit knowledge is non-codifiable and can be fully understood only by those who are present in the socio-economic context where borrowers operate. The definition of tacit knowledge is closely related to the definition of soft information in the relationship lending literature.
} 
Flores, 1990). These researches explained this by the fact that external factors or unusual events will be captured by forecasters and cannot be extrapolated from the past. The majority of these papers concluded that judgment would play an important role in macro-economic forecasting and that analysts' forecasts possess better and more up-to-date information.

In lending context, Lipshitz and Shulimovitz (2007) used interviews of fourteen loan officers at a large commercial bank and concluded that "gut feelings" are regarded as more valid indicator of the worthiness of the application than the relevant financial data. Impressions and feelings have a more positive view by considering these factors as a valuable source of information, especially for experienced loan officers in repeated transactions. More recently, Heikkilä (2011) examined whether loan officers' judgment and tacit knowledge about their clients results in more effective screening and monitoring work, and consequently better loan repayment outcomes. She used the rotation of loan officers as a proxy for the loan officers' tacit knowledge. Using data from Ugandan cooperative MFI, Heikkilä (2011) utilized a natural experiment by using two subsamples, the first one contains the portfolios of the rotated officers and the second one contains the non-rotated officers. She found that the tacit knowledge of loan officer and his personal assessment have a positive effect on repayment rates via screening of borrowers, but no effect via officers' monitoring work.

\subsection{Predictive accuracy of Soft information and strength of lender-borrower relationship}

From a theoretical viewpoint, there is a wide consensus that the quality of soft information increases through the interaction between borrowers and lenders. Previous studies focused on how banks mitigate adverse selection problems with their clients during the screening process by accumulating soft information about borrowers' quality and behaviour (Cole, 1998; Petersen \& Rajan, 1994; Stein, 2002). The strength of relationship with the entrepreneur increases with the experience of loan officer and with the frequency of contact. The greater the loan officer's experience and the most frequent the loan officer-entrepreneur relationship, the more accurate soft information he/she will produce. Uchida, Yamori, and Udell (2012) found that the production of soft information increases with skill level of loan officer (e.g., loan officer turnover, loan officer age) and loan officer lending activities (e.g., frequency of meeting and method of contact). In recent study, loan officer turnover is introduced as a potentially better proxy of the quality of soft information produced than length of banking relationship. More soft information tends to be accumulated when loan officer turnover is less.

\section{Do individual forecasters learn from their experience: The cognitive view on expertise}

The learning process with forecasters and decision makers is not well-understood and the results regarding individual learning seem to be mixed. Theories on intuition as a component of professional competence suggest the experts are superior to novices because of their experience and their relevant implicit and explicit knowledge. Intuition is not an innate capabilities, it is grounded on knowledge developed with professional learning. The cognitive process and learning from experience played a major role in judgment and decision performance. In the last 25 years, large literature investigated the effect of forecaster expertise on predictive accuracy and found that experts gave better prediction accuracy than novices (Harteis \& Gruber, 2008; List, 2003; Muradoglu \& Onkal, 1994) because experience helps investors reduce certain behavioral biases through learning (Gervais \& Odean, 2001). However, others studies (Einhorn \& Hogarth, 1978; Heaton, 2002) concluded that learning from experience eliminate behavior biases only with similar and repetitive task. For example, investment decisions or financial decisions of entrepreneur are not frequent, the outcomes are often delayed for long periods of time, and feedback is typically very noisy. Delayed feedback makes it more difficult for decision-makers to learn from their mistakes (Shanteau, 1992).

In our context, as lending decision in MFI is a repetitive task with dynamic feedback (Microcredit have often short repayment terms), we can assume that experienced loan officer have less behavior bias than novice. Agier and Szafarz (2012) decomposed unjustified gender gap caused by judgmental bias of loan officers in eleven one-year sub-periods. They found that subjective bias of loan officers decreases with time, evolving from 
$38 \%$ in 1997 to $7 \%$ in 2007. Hence, they conclude that this could signal that some favourable kind of learning and adjustment process has taken place with time in the MFI.

However, Andersson (2004) argued that the experienced loan officer's judgment to borrowers risk is affected by the degree of confidence they attribute to the acquired information (Overconfidence). Using in-depth interviews, Andersson (2004) studied the behaviour of expert lenders in Sweden. Based on previous research in psychology, he assumed that experienced lenders would acquire less information and that experience could be linked with more accurate attitudes towards risk. However, the findings indicated that experience does not unambiguously lead to specific and superior judgment behaviour and that expert loan officers tend to acquire more cues across all the information. Andersson (2004) related this result to the phenomenon of overconfidence: overconfidence occurs even among experienced professionals making routine professional judgments acquired more cues but a corresponding increase in the decision accuracy may not occur.

\section{Does frequency of contact matter?}

Through the development of long-term and sustainable relationships in which mutual trust and understanding will grow, loan officer will have more accurate feeling and will acquire more valuable soft information about the potential borrowers. Consequently, he will be able to adjust the credit evaluation process and to make an accurate default prediction. Cornée et al. (2009) found that subjective judgements are positively influenced by the long-term lender-borrower relationship. Therefore, the quality of soft information depends on frequency of contact with the bank measured as the average number of contacts.

In addition, behavioral biases like overconfidence are generally strong in uncertain environments characterized by incomplete information about an alternative or high degree of complexity. Hence, for new client with low bank-borrower relationship characterized by a stronger information asymmetries and substantial uncertainty about their ability to repay loans, we can assume that loan officer in MFI will be prone to be overconfident. The increase of borrower-lender relationship decreases information uncertainty and hence decreases behavior bias. This means that loan officer's subjective judgements convey less prediction error when there is a relationship between the bank and the borrower prior to the credit granting decision. Agier and Szafarz (2012) decomposed unjustified gender gap for all applicants into newcomers and known clients. They found that the subjective bias created by loan officer decrease from $43.5 \%$ for newcomers to $18.1 \%$ for known applicants. Their result confirms that the presence of personal contact between borrowers and loan officer decreases the predictive errors of loan officer.

However, it may be important to note that it quite difficult for the loan officer to communicate the soft information to others in the bank. Hence, we can expect that the positive relation between predictive accuracy of loan officer judgement and contact frequency will be confirmed only for experienced loan officers.

\section{Data and methodology}

In order to evaluate the prediction accuracy of subjective judgment of loan officers, we first investigate the significance and the predictive accuracy of soft information. Next, we explore the relation between predictive accuracy of soft information and strength of lender-borrower relationship measured by loan officer experience and the frequency of contact with the microfinance institution.

We obtain a large dataset from Solidarity Tunisian Bank, a Microfinance bank whose lending practice has concentrated on financing private micro-projects of micro-entrepreneurs. In the credit granting process of this bank, loan officers encounter entrepreneurs and collect personal information on them and on their business characteristics. After the encounter, loan officers assess expected cash flows of project and assess borrower's character during field visits. They estimate the borrower's creditworthiness based on their own judgment. Finally, loan officers make recommendations to the credit committee that in turn has the final say on both loan approval 
and loan size.

The data set contains 5022 applications received and granted between 2004 and 2009. From them, 39.7\% turned out to default and $60.3 \%$ performed well. Dependent variable is the credit status of the customer. It is created based on expert advice from the institution, who define a "Bad" borrowers as the applicant who did not repay their loans at due date (legal follow-up). It is explained by two values as follow:

$$
Y_{i}=\left\{\begin{array}{l}
0 \text { if borrower having non-defaulted debt } \\
1 \text { if borrower having defaulted debt }
\end{array}\right.
$$

Soft information is defined as the subjective judgment given by the loan officer at the time of examination of the credit application. It is a dummy variable that take the value 1 if subjective assessment given by the loan officer regarding the soundness of the project of borrower after the field visits is "Good", and 0 otherwise (Bad). Hard information is verifiable and easily transmittable information related to credit. It includes socio-demographical variables, loan characteristics variables and past loans behavioral variables. The detailed variables description is provided in Table 1.

To examine whether the bank's soft information matters in predicting loan defaults, we explicitly explore this relationship with the following logistic regression model:

$$
\operatorname{Pr}(\text { default })=\log \left(\frac{P_{i}}{1-P_{i}}\right)=\beta_{0}+\beta_{n m} X_{S O F T}+\beta_{n m} X_{H A R D}
$$

- $\beta_{0}:$ the intercept

- $\beta_{n m}:$ the regression coefficient

- $X_{S O F T}$ : dummy coded soft variable

- $X_{H A R D}$ : dummy coded hard variables

\section{Table 1}

Definition of variables

\begin{tabular}{l|l}
\hline \multicolumn{1}{c}{ Variables } & \multicolumn{1}{c}{ Description of variable } \\
\hline $\mathrm{X}_{1}=$ Age of the borrower & $\begin{array}{l}\text { Less than } 22\left(X_{11}\right), 23-25\left(X_{12}\right), 26-34\left(X_{13}\right), 35-40\left(X_{14}\right), 41-45\left(X_{15}\right), \\
\text { More than } 45\left(X_{16}\right)\end{array}$ \\
\hline $\mathrm{X}_{2}=$ Gender of the borrower & Male $\left(X_{21}\right)$, Female $\left(X_{22}\right)$ \\
\hline $\mathrm{X}_{3}=$ Marital Status & Single $\left(\mathrm{X}_{31}\right)$, Married, Divorced, Widowed $\left(\mathrm{X}_{32}\right)$ \\
\hline $\mathrm{X}_{4}=$ Educational level & $\begin{array}{l}\text { Lower educational level }\left(X_{41}\right), \text { Graduate and higher educational level } \\
\left(X_{42}\right)\end{array}$ \\
\hline $\mathrm{X}_{5}=$ Job experience & $<2$ years $\left(X_{51}\right), 2-4$ years $\left(X_{52}\right), 4-7$ years $\left(X_{53}\right),>7$ years $\left(X_{54}\right)$ \\
\hline & Loan characteristics variables \\
\hline $\mathrm{X}_{6}=$ Credit amount & $\begin{array}{l}\text { Less than } 1935 \quad\left(X_{61}\right),[1936-2400] \quad\left(X_{62}\right),[2400-3599] \\
{[3599-4350]\left(X_{64}\right),[4350-4999]\left(X_{65}\right),[4999-5919]\left(X_{66}\right),[5919-8832]} \\
\left(X_{67}\right), \text { More than } 8832\left(X_{68}\right)\end{array}$ \\
\hline$X_{7}=$ Credit purpose & Business Creation $\left(X_{71}\right)$, Business extension $\left(X_{72}\right)$ \\
\hline$X_{8}=$ Business sector & Agriculture $\left(X_{81}\right)$, Services $\left(X_{82}\right)$, Artisanal $\left(X_{83}\right)$, Small Trades $\left(X_{84}\right)$ \\
\hline & \multicolumn{1}{c}{ Behavioural variables } \\
\hline$X_{9}=$ Number of previous loans & Two loans $\left(X_{91}\right)$, One loan $\left(X_{92}\right)$, New customer $\left(X_{93}\right)$ \\
\hline$X_{10}=$ Previous loans default & $\begin{array}{l}\text { New customer }\left(X_{101}\right), \text { all credit paid back duly }\left(X_{102}\right), \text { delay in paying } \\
\text { off in the past }\left(X_{103}\right)\end{array}$ \\
\hline & \multicolumn{1}{c}{ Soft variable } \\
\hline$X_{\text {Soft }}=$ Subjective Judgment & Good score $\left(X_{S o f t 1}\right)$ \\
\hline & Bad score $\left(X_{S o f t 2}\right)$ \\
\hline
\end{tabular}


Baklouti, I. \& Baccar, A.

Then, we re-run this regression using sub-samples of loans with and without the strength banking relationship, respectively. We adopt two proxies for the strength of lending relationship. Our first proxy is based on the loan officer' experience. The experience of loan officer variable is the number of years spent by the loan officer in the bank at the time of the credit loan conclusion. The group of novices was those subjects with up to 6 years of experience. The group of experts was those with more than 6 years of experience ${ }^{3}$. Our second proxy is based on the borrowing frequency over the sample period. For each borrower, we compute the total number of loans outstanding with the bank over the sample period. We classify a client as frequent borrower if its number of loans outstanding is greater than one credit. Otherwise, infrequent borrower is classified as client having one credit. Since one of hard variable is the number of previous loans (Borrowing frequency), we remove this variable from the set of independent variables.

\section{Empirical results}

\subsection{Predictive accuracy of subjective judgment}

Table 2 reveals that both soft and hard factors are statistically significant. This suggests that subjective judgment completes rather than substitutes hard information in the prediction of loan defaults ${ }^{4}$. More importantly, soft factor $\left(X_{S o f t}\right)$ is significantly negatively related to the probability of default. The borrower who has received a "good" rating from the loan officer is less likely to default than borrower receiving a "bad" rating, ceteris paribus. We can conclude from this the accurate performance of soft information produced by loan officers in relationship lending. Tacit knowledge concerns interpersonal relationships skills and includes the use of intuition, feelings and emotional intelligence that are not so easily expressed but may be demonstrated as skills and competences. This result goes against the result of Daniel Kahneman and the Amos Tversky who have concluded that intuition of average people is subject to errors.

Table 2

Predictive accuracy of soft information

\begin{tabular}{lll}
\hline \multicolumn{1}{c}{ Variable } & & Overall sample \\
\hline Intercept $\mathrm{X}_{0}$ & & $1.716^{*}(0.491)$ \\
Age of the borrower $X_{1}$ & Less than $22\left(X_{11}\right)$ & $-0.233(0.218)$ \\
& $23-25\left(X_{12}\right)$ & $-0.046(0.232)$ \\
& $26-34\left(X_{13}\right)$ & $0.340^{* * * *}(0.181)$ \\
& $35-40\left(X_{14}\right)$ & $0.388^{* *}(0.185)$ \\
& $41-45\left(X_{15}\right)$ & $0.038(0.215)$ \\
& More than $45\left(X_{16}\right)$ & $0.0000 \mathrm{~N} / \mathrm{A}$ \\
\hline Gender of the borrower $\mathrm{X}_{2}$ & Male $\left(X_{21}\right)$ & $0.301^{*}(0.102)$ \\
& Female $\left(X_{22}\right)$ & $0.0000 \mathrm{~N} / \mathrm{A}$ \\
\hline Marital Status $\mathrm{X}_{3}$ & Single $\left(\mathrm{X}_{31}\right)$ & $0.349^{*}(0.108)$ \\
& Married. Divorced. Widowed $\left(\mathrm{X}_{32}\right)$ & $0.0000 \mathrm{~N} / \mathrm{A}$ \\
\hline Educational level $\mathrm{X}_{4}$ & Lower educational level $\left(X_{41}\right)$ & $-2.488^{*}(0.177)$ \\
\hline Loan characteristics variables & Graduate and higher educational level $\left(X_{42}\right)$ & $0.0000 \mathrm{~N} / \mathrm{A}$ \\
\hline Credit amount $\mathrm{X}_{6}$ & & $3.239^{*}(0.251)$ \\
& Less than $1935\left(X_{61}\right)$ & $2.265^{*}(0.237)$ \\
& {$\left[1936,2400\left[\left(X_{62}\right)\right.\right.$} & $1.620^{*}(0.205)$ \\
& {$\left[2400,3599\left[\left(X_{63}\right)\right.\right.$} & $1.224^{*}(0.223)$ \\
& {$\left[3599,4350\left[\left(X_{64}\right)\right.\right.$} & $1.427^{*}(0.237)$ \\
& {$\left[4350,4999\left[\left(X_{65}\right)\right.\right.$} & $1.426^{*}(0.218)$ \\
& {$\left[4999,5919\left[\left(X_{66}\right)\right.\right.$} & $-0.580^{*}(0.198)$ \\
& {$\left[5919,8832\left[\left(X_{67}\right)\right.\right.$} & $0.0000 \mathrm{~N} / \mathrm{A}$ \\
\hline
\end{tabular}

\footnotetext{
3 This variable is created based on advice from the manager of Tunisian Microfinance institution.

${ }^{4}$ As we have used forward stepwise technique, all statistically insignificant variables are eliminated. From Table 2, we conclude that $\mathrm{X}_{5}, \mathrm{X}_{7}$ and $\mathrm{X}_{10}$ have insignificant coefficients
} 
Table 2 ... continue

Predictive accuracy of soft information

\begin{tabular}{cll}
\hline \multicolumn{1}{c}{ Variable } & & Overall sample \\
\hline Business sector $X_{8}$ & Agriculture $\left(X_{81}\right)$ & $-4.722^{*}(0.425)$ \\
& Services $\left(X_{82}\right)$ & $0.188^{* *}(0.094)$ \\
& Artisanal $\left(X_{83}\right)$ & $0.024(0.233)$ \\
Behavioural variables & Small Trades $\left(X_{84}\right)$ & 0.0000 N/A \\
\hline Number of previous loans $X_{9}$ & & $0.931^{*}(0.173)$ \\
& One loan $\left(X_{91}\right)$ & $0.047(0.447)$ \\
\hline Subjective Judgment $X_{\text {Soft }}$ & Two loans $\left(X_{92}\right)$ & 0.0000 N/A \\
\hline & New customer $\left(X_{93}\right)$ & $-0.670^{*}(0.088)$ \\
\hline
\end{tabular}

Note. $*$ Variable significant at 1\%, ** Variable significant at 5\%, ***Variable significant at $10 \%$.

\subsection{Predictive accuracy of subjective judgment and the strength of lending relationships: loan officer's} experience and frequency of contact

Based on the results presented in Table 3, our findings suggest that the role of subjective assessment information in predicting loan defaults varies depending on the depth of the lending relationship.

Table 3

Subjective judgment accuracy and the strength of lending relationships

\begin{tabular}{|c|c|c|c|c|c|}
\hline & & \multicolumn{2}{|c|}{ Loan officer experience } & \multicolumn{2}{|c|}{ Borrowing frequency } \\
\hline & & $\begin{array}{l}\text { Novice } \\
\text { (1) }\end{array}$ & $\begin{array}{l}\text { Expert } \\
(2)\end{array}$ & $\begin{array}{l}\text { Frequent } \\
\text { (3) }\end{array}$ & $\begin{array}{c}\text { Infrequent } \\
\text { (4) }\end{array}$ \\
\hline \multirow[t]{3}{*}{$X_{\text {Soft }}$} & $\left(X_{S o f t I}\right)$ & $1.452^{*}(0.108)$ & $-5.556^{*}(0.353)$ & $0.331(0.223)$ & $-0.861^{* *}(0.094)$ \\
\hline & & {$[0.328]$} & {$[-0.608]$} & {$[0.08]$} & {$[-0.206]$} \\
\hline & $\left(X_{S o f t 2}\right)$ & $0.0000 \mathrm{~N} / \mathrm{A}$ & $0.0000 \mathrm{~N} / \mathrm{A}$ & $0.0000 \mathrm{~N} / \mathrm{A}$ & $0.0000 \mathrm{~N} / \mathrm{A}$ \\
\hline $\mathrm{X}_{0}$ & & $-1.234^{*}(0.299)$ & $5.090^{*}(0.664)$ & $0.176(0.577)$ & $0.774^{*}(0.296)$ \\
\hline \multirow[t]{6}{*}{$\mathrm{X}_{1}$} & $\left(X_{11}\right)$ & $-0.190(0.247)$ & $-0.724(0.573)$ & $-0.057(0.577)$ & $-0.413^{* * *}(0.139)$ \\
\hline & $\left(X_{12}\right)$ & $-0.007^{* * * *}(0.260)$ & $-0.433(0.580)$ & $0.353(0.610)$ & $-0.023(0.255)$ \\
\hline & $\left(X_{13}\right)$ & $0.412^{* *}(0.206)$ & $0.476(0.454)$ & $0.473(0.476)$ & $0.83^{* * *}(0.202)$ \\
\hline & $\left(X_{14}\right)$ & $0.496^{* *}(0.209)$ & $0.535^{* *}(0.460)$ & $0.283(0.486)$ & $0.380^{* * *}(0.206)$ \\
\hline & $\left(X_{15}\right)$ & $0.293(0.236)$ & $0.129(0.515)$ & $-0.729(0.623)$ & $0.278(0.236)$ \\
\hline & $\left(X_{16}\right)$ & $0.0000 \mathrm{~N} / \mathrm{A}$ & $0.0000 \mathrm{~N} / \mathrm{A}$ & $0.0000 \mathrm{~N} / \mathrm{A}$ & $0.0000 \mathrm{~N} / \mathrm{A}$ \\
\hline \multirow[t]{2}{*}{$\mathrm{X}_{2}$} & $\left(X_{21}\right)$ & $0.252^{* *}(0.111)$ & $-0.221(0.252)$ & $0.148(0.239)$ & $0.225^{*}(0.109)$ \\
\hline & $\left(X_{22}\right)$ & $0.0000 \mathrm{~N} / \mathrm{A}$ & $0.0000 \mathrm{~N} / \mathrm{A}$ & $0.0000 \mathrm{~N} / \mathrm{A}$ & $0.0000 \mathrm{~N} / \mathrm{A}$ \\
\hline \multirow[t]{2}{*}{$\mathrm{X}_{3}$} & $\left(X_{31}\right)$ & $0.390^{*}(0.166)$ & $0.675^{* *}(0.297)$ & $0.003(0.258)$ & $0.335^{*}(0.116)$ \\
\hline & $\left(X_{32}\right)$ & 0.0000 N/A & $0.0000 \mathrm{~N} / \mathrm{A}$ & $0.0000 \mathrm{~N} / \mathrm{A}$ & $0.0000 \mathrm{~N} / \mathrm{A}$ \\
\hline \multirow[t]{2}{*}{$\mathrm{X}_{4}$} & $\left(X_{41}\right)$ & $-1.868^{*}(0.182)$ & $-3.376^{*}(0.408)$ & $-1.453^{*}(0.338)$ & $-3.051^{*}(0.223)$ \\
\hline & $\left(X_{42}\right)$ & $0.0000 \mathrm{~N} / \mathrm{A}$ & 0.0000 N/A & $0.0000 \mathrm{~N} / \mathrm{A}$ & 0.0000 N/A \\
\hline \multirow[t]{8}{*}{$\mathrm{X}_{6}$} & $\left(X_{61}\right)$ & $2.344^{*}(0.259)$ & $3.209^{*}(0.610)$ & $-7.11^{* * * *}(2.251)$ & $3.394^{*}(0.292)$ \\
\hline & $\left(X_{62}\right)$ & $1.676 *(0.260)$ & $2.311^{*}(0.559)$ & $2.889^{* *}(1.237)$ & $2.660 *(0.284)$ \\
\hline & $\left(X_{63}\right)$ & $1.402^{*}(0.222)$ & $1.858^{*}(0.482)$ & $1.109(0.271)$ & $2.106^{*}(0.258)$ \\
\hline & $\left(X_{64}\right)$ & $1.040 *(0.238)$ & $0.758(0.527)$ & $0.413(0.423)$ & $1.723^{*}(0.275)$ \\
\hline & $\left(X_{65}\right)$ & $1.200^{*}(0.248)$ & $0.730(0.572)$ & $0.228(0.447)$ & $1.567^{*}(0.291)$ \\
\hline & $\left(X_{66}\right)$ & $1.206^{*}(0.216)$ & $1.076^{* *}(0.518)$ & $0.267^{*}(0.418)$ & $1.784 *(0.274)$ \\
\hline & $\left(X_{67}\right)$ & $0.567^{* * *}(0.222)$ & $0.514(0.454)$ & $0.835^{*}(0.398)$ & $0.916^{*}(0.254)$ \\
\hline & $\left(X_{68}\right)$ & $0.0000 \mathrm{~N} / \mathrm{A}$ & $0.0000 \mathrm{~N} / \mathrm{A}$ & $0.0000 \mathrm{~N} / \mathrm{A}$ & $0.0000 \mathrm{~N} / \mathrm{A}$ \\
\hline \multirow[t]{4}{*}{$\mathrm{X}_{8}$} & $\left(X_{81}\right)$ & $-3.860^{*}(0.463)$ & $-5.143^{*}(0.567)$ & $-3.178^{*}(0.791)$ & $-4.726^{*}(0.425)$ \\
\hline & $\left(X_{82}\right)$ & $0.025(0.102)$ & $0.543^{* *}(0.240)$ & $0.293(0.238)$ & $0.098(0.100)$ \\
\hline & $\left(X_{83}\right)$ & $0.204(0.277)$ & $0.649(0.534)$ & $1.184^{* * *}(0627)$ & $0.082(0.253)$ \\
\hline & $\left(X_{84}\right)$ & $0.0000 \mathrm{~N} / \mathrm{A}$ & $0.0000 \mathrm{~N} / \mathrm{A}$ & $0.0000 \mathrm{~N} / \mathrm{A}$ & $0.0000 \mathrm{~N} / \mathrm{A}$ \\
\hline \multicolumn{2}{|c|}{$\mathrm{Nb} . \mathrm{Obs}$} & 2005 & 3017 & 418 & 4604 \\
\hline
\end{tabular}


Table 3... continue

Subjective judgment accuracy and the strength of lending relationships

\begin{tabular}{|c|c|c|c|c|c|}
\hline & & \multicolumn{2}{|c|}{ Novice Loan officers } & \multicolumn{2}{|c|}{ Expert Loan officers } \\
\hline & & $\begin{array}{l}\text { Frequent } \\
\text { (5) }\end{array}$ & $\begin{array}{c}\text { Infrequent } \\
\text { (6) }\end{array}$ & $\begin{array}{l}\text { Frequent } \\
\text { (7) }\end{array}$ & $\begin{array}{c}\text { Infrequent } \\
\text { (8) }\end{array}$ \\
\hline \multirow{3}{*}{$X_{S o f t}$} & $\left(X_{\text {Soft } 1}\right)$ & $2.978^{*}(0.454)$ & $1.340^{*}(0.114)$ & $-4.143^{*}(1.034)$ & $-0.815^{*}(0.258)$ \\
\hline & & {$[0.6]$} & {$[0.298]$} & {$[-0.309]$} & {$[-0.019]$} \\
\hline & $\left(X_{S o f t 2}\right)$ & $0.0000 \mathrm{~N} / \mathrm{A}$ & $0.0000 \mathrm{~N} / \mathrm{A}$ & $0.0000 \mathrm{~N} / \mathrm{A}$ & $0.0000 \mathrm{~N} / \mathrm{A}$ \\
\hline $\mathrm{X}_{0}$ & & $-2.070(0.996)$ & $-1.266^{*}(14.248)$ & $4.912^{* * * *}(2.648)$ & $4.095^{*}(0.702)$ \\
\hline \multirow[t]{6}{*}{$\mathrm{X}_{1}$} & $\left(X_{11}\right)$ & $-0.237(0.947)$ & $-0.240(0.262)$ & $1.453(2.456)$ & $-0.774^{* * *}(0.587)$ \\
\hline & $\left(X_{12}\right)$ & $-0.287(0.982)$ & $-0.035(0.275)$ & $-0.004(2.002)$ & $-0.431(0.605)$ \\
\hline & $\left(X_{13}\right)$ & $0.320(0.849)$ & $0.369^{* * * *}(0.216)$ & $1.262(1.897)$ & $0.433(0.481)$ \\
\hline & $\left(X_{14}\right)$ & $0.529(0.873)$ & $0.533^{* *}(0.220)$ & $2.537(2.183)$ & $0.242(0.490)$ \\
\hline & $\left(X_{15}\right)$ & $0.557(1.055)$ & $0.342(0.247)$ & $-0.224(1.993)$ & $0.384(0.540)$ \\
\hline & $\left(X_{16}\right)$ & $0.0000 \mathrm{~N} / \mathrm{A}$ & $0.0000 \mathrm{~N} / \mathrm{A}$ & $0.0000 \mathrm{~N} / \mathrm{A}$ & $0.0000 \mathrm{~N} / \mathrm{A}$ \\
\hline \multirow[t]{2}{*}{$\mathrm{X}_{2}$} & $\left(X_{21}\right)$ & $0.088(0.355)$ & $0.354^{*}(0.119)$ & $-0.028(1.024)$ & $0.096(0.255)$ \\
\hline & $\left(X_{22}\right)$ & $0.0000 \mathrm{~N} / \mathrm{A}$ & $0.0000 \mathrm{~N} / \mathrm{A}$ & $0.0000 \mathrm{~N} / \mathrm{A}$ & $0.0000 \mathrm{~N} / \mathrm{A}$ \\
\hline \multirow[t]{2}{*}{$\mathrm{X}_{3}$} & $\left(\mathrm{X}_{31}\right)$ & $0.430(0.397)$ & $0.354^{*}(0.125)$ & $1.333(1.065)$ & $0.128(0.279)$ \\
\hline & $\left(X_{32}\right)$ & $0.0000 \mathrm{~N} / \mathrm{A}$ & $0.0000 \mathrm{~N} / \mathrm{A}$ & $0.0000 \mathrm{~N} / \mathrm{A}$ & $0.0000 \mathrm{~N} / \mathrm{A}$ \\
\hline \multirow[t]{2}{*}{$\mathrm{X}_{4}$} & $\left(X_{41}\right)$ & $-1.13^{* * *}(0.480)$ & $-2.325^{*}(0.224)$ & $-2.078(1.377)$ & $-5.057^{*}(0.546)$ \\
\hline & $\left(X_{42}\right)$ & $0.0000 \mathrm{~N} / \mathrm{A}$ & $0.0000 \mathrm{~N} / \mathrm{A}$ & $0.0000 \mathrm{~N} / \mathrm{A}$ & $0.0000 \mathrm{~N} / \mathrm{A}$ \\
\hline \multirow[t]{8}{*}{$\mathrm{X}_{6}$} & $\left(X_{61}\right)$ & $1.245(2.291)$ & $2.831^{*}(0.314)$ & $16.491(2.299)$ & $6.429^{*}(0.737)$ \\
\hline & $\left(X_{62}\right)$ & $3.666(4.071)$ & $2.176^{*}(0.316)$ & $2.128(2.009)$ & $4.989^{*}(0.696)$ \\
\hline & $\left(X_{63}\right)$ & $1.438^{* * *}(0.773)$ & $1.893^{*}(0.286)$ & $-0.479(1.691)$ & $4.444^{*}(0.641)$ \\
\hline & $\left(X_{64}\right)$ & $0.248(0.752)$ & $1.555^{*}(0.298)$ & $1.334(1.618)$ & $3.204^{*}(0.666)$ \\
\hline & $\left(X_{65}\right)$ & $0.018(0.620)$ & $1.750^{*}(0.308)$ & $-0.425(1.623)$ & $2.837^{*}(0.702)$ \\
\hline & $\left(X_{66}\right)$ & $0.076(0.636)$ & $1.704^{*}(0.295)$ & $0.167(1.000)$ & $3.758^{*}(0.677)$ \\
\hline & $\left(X_{67}\right)$ & $0.607(0.438)$ & $0.825^{*}(0.284)$ & $1.784^{*}(0.295)$ & $0.106(0.546)$ \\
\hline & $\left(X_{68}\right)$ & $0.0000 \mathrm{~N} / \mathrm{A}$ & $0.0000 \mathrm{~N} / \mathrm{A}$ & $0.0000 \mathrm{~N} / \mathrm{A}$ & $0.0000 \mathrm{~N} / \mathrm{A}$ \\
\hline \multirow[t]{4}{*}{$\mathrm{X}_{8}$} & $\left(X_{81}\right)$ & $-8.792(6.986)$ & $-3.804^{*}(0.464)$ & $-2.610^{* * * *}(1.438)$ & $-6.474^{*}(0.696)$ \\
\hline & $\left(X_{82}\right)$ & $0.213(0.359)$ & $-0.006(0.109)$ & $1.378(0.901)$ & $0.133(0.241)$ \\
\hline & $\left(X_{83}\right)$ & $0.594(0.815)$ & $-0.382(0.309)$ & $17.895(4.464)$ & $0.053(0.551)$ \\
\hline & $\left(X_{84}\right)$ & $0.0000 \mathrm{~N} / \mathrm{A}$ & $0.0000 \mathrm{~N} / \mathrm{A}$ & $0.0000 \mathrm{~N} / \mathrm{A}$ & $0.0000 \mathrm{~N} / \mathrm{A}$ \\
\hline $\mathrm{Nb} . \mathrm{Obs}$ & & 133 & 1872 & 285 & 2732 \\
\hline
\end{tabular}

Columns (1) and (2) of Table 3 show that subjective judgment of experienced loan officer is significantly negatively related to the probability of default while subjective judgment of novice expert loan officer is significantly positively related to the probability of default. The borrower who has received a "good" rating from experienced loan officer (novice loan officer) is less (more) likely to default than borrower receiving a "bad" rating, ceteris paribus. From these results, we can conclude that subjective judgment of expert has a positive forecast quality but subjective judgment of novice has a negative forecast quality. In this case, novice loan officers are prone to different behavioral biases. Through learning, loan officers will have cognitive and emotional competences that help them gain access, assessment and weighting intangible borrower characteristics.

It is important to note the effect of subjective judgment in overall sample ( $\beta=-0.670^{*}$ ) (see Table 2 ) is significantly negative because the proportion of experienced loan officers in total sample $(60 \%)$ is larger than the proportion of novice loan officers. While the effect of subjective judgment is not related to the probability of default in column (3), column (4) indicates that subjective judgment of loan officers is significantly negatively related to the probability of default of infrequent loans.

Column (5) and column (6) show that while subjective judgment of novice loan officer is significantly positively related to default, the marginal effect of soft information tends to be larger among frequent borrowers. This means that while the increase of borrower-lender relationship decreases information uncertainty, novice 
Evaluating the predictive accuracy of microloan officers' subjective judgment

loan officer may overweight any information that is consistent with their existing beliefs and overestimate the precision of their own private information. In addition, this confirms the result of many researchers, which conclude that soft information is not easily and accurately transferable (Peterson, 2004).

For experienced loan officer, column (7) and column (8) suggest that more favorable soft information leads to a lower probability of default mainly for frequent borrowers. Through the development of long-term and sustainable relationships in which mutual trust and understanding will grow, experienced loan officer will have more accurate feeling and will acquire more valuable soft information about the potential borrowers. Consequently, he will be able to adjust the credit evaluation process and to make an accurate default prediction.

Despite the fact that the economic impact of soft information is significantly more pronounced among borrowers with a higher level of relationship, the experienced loan officer' soft information remain decreasing the default for loan $\left(\beta=-0.815^{*}\right)$. In fact, although the absence of certain information with infrequent borrower (e.g. previous credit performance), experienced loan officer will have a good and accurate feeling and competence to predict borrower creditworthiness. Regardless of the frequency of borrower, experienced loan officers have more accurate soft information predicting default than novice loan officer. Consequently, MFI have more interest to retain their experienced loan officer than their borrowers.

\section{Conclusion}

\subsection{Findings}

The peculiarity in lending methodology in MFI characterized by unchallenged dominance of the loan officers in the decision-making prompted us to investigate the predictive accuracy of soft information. This paper permits us to gain a better understanding of loan officer behavior in default prediction task. Our main result is that experienced loan officers have more accurate soft information than novice loan officer, regardless of the frequency of borrower. Consequently, microfinance institution has more interest to retain their experienced loan officer than their borrowers. To make accurate decision in relationship lending approach, credit committee can rely on subjective judgment of experienced loan officers mainly when the latter judged the creditworthiness of frequent borrowers. However, credit committee should not rely on subjective judgment of novice loan officers because their subjective judgments produce inconsistent credit ratings.

\subsection{Theoretical and practical implications}

Our paper has theoretical and practical implications. Largely neglected in the literature, our paper presented a theoretical overview of the role of subjective information of loan officer in default prediction task. Our paper has also practical implications for Microfinance institution. MFI will be able to enhance their granting decisions and to enable their subjective system to shape accurate responses. This allow to diminish possible risks associated with customers' payment defaults that may result in heavy losses, reduce arrears and so reduce time spent collecting overdue payments from delinquent borrowers. This greater efficiency improves both breadth of outreach (number of loans) and sustainability.

\subsection{Recommendations}

Our result provides possible extensions that aim to gain a more refined understanding of the the difference between loan officers successful in forecasting borrowers' credit risk. For example, qualitative research can be conducted in order to reveal behavioral factors of loan officers that can explain this difference.

\section{References:}

Agier, I., \& Szafarz, A. (2012). Subjectivity in credit allocation to micro-entrepreneurs: Evidence from Brazil. 
Small Business Economics, 38, 1-13.

Andersson, P. (2004). Does experience matter in lending? A process-tracing study on experienced loan officers' and novices' decision behavior. Journal of Economic Psychology, 25(4), 471-492. http://dx.doi.org/10.1016/S0167-4870(03)00030-8

Barasinska, N. (2009). The role of gender in lending business: Evidence from an online market for peer-to-peer lending. DIW Berlin working paper.

Blanchard, L., Zhao, B., \& Yinger, J. (2008). Do lenders discriminate against minority and woman entrepreneurs?. Journal of Urban Economics, 63(2), 467-497. http://dx.doi.org/10.1016/j.jue.2007.03.001

Blanchflower, D. G., Levine, P. B., \& Zimmerman, D. J. (2003). Discrimination in the small-business credit market. Review of Economics and Statistics, 85(4), 930-943. http://dx.doi.org/10.1162/003465303772815835

Bonabeau, E. (2003). Don't trust your gut. Harvard Business Review, 81(5), 116-123.

Carter, S., Shaw, E., Lam, W., \& Wilson, F. (2007). Gender, entrepreneurship and bank lending: the criteria and processes used by bank loan officers in assessing applications. Entrepreneurship: Theory and Practice, 31(3), 427-44. http://dx.doi.org/10.1111/j.1540-6520.2007.00181.x

Cavalluzzo, K. S., \& Cavalluzz, L. C. (1998). Market structure and discrimination: The case of small businesses. Journal of Money Credit and Banking, 30(4), 771-792. http://dx.doi.org/10.1086/497045

Cavalluzzo, K., \& Wolken, J. (2005). Small business loan turndowns, personal wealth and discrimination. Journal of Business, 78(6), 2153-2177. http://dx.doi.org/10.2307/2601128

Cole, R. A. (1998). The importance of relationships to the availability of credit. Journal of Banking and Finance, 22, 959-977. http://dx.doi.org/10.1016/S0378-4266(98)00007-7

Cornée, S., Masclet, D., \& Thenet, G. (2009). Long-term relationship and reciprocity in credit market experiment: Implications for microfinance. Paper presented in $26^{\text {th }}$ Symposium on Money, Banking and Finance, Juin, Orléans. Available from http://halshs.archives-ouvertes.fr/halshs-00391561

Dixon, R., Ritchie, J., \& Siwale, J. (2007). Loan officers and loan 'delinquency' in microfinance: a Zambian case. Accounting Forum, 31(1), 47-71. http://dx.doi.org/10.1016/j.accfor.2006.11.005

Edmundson, R. H., Lawrence, M. J., \& O'Connor, M. (1988). The use of non time-series information in sales forecasting: A case study. Journal of Forecasting, 7(3), 201-211. http://dx.doi.org/10.1002/for.3980070305

Einhorn, H. J., \& Hogarth, R. M. (1978). Confidence in Judgment: Persistence of the Illusion of Validity. Psychological Review, 85(5), 395-416. http://dx.doi.org/10.1037/0033-295X.85.5.395

Gervais, S., \& Odean, T. (2001). Learning to be overconfident. Review of Financial Studies, 14(1), 1-27. http://dx.doi.org/10.1093/rfs/14.1.1

Grunert, J., Norden, L., \& Weber, M. (2005). The role of non-financial factors in internal credit ratings. Journal of Banking and Finance, 29(2), 509-531. http://dx.doi.org/10.1016/j.jbankfin.2004.05.017

Harteis, C., \& Gruber, H. (2008). Intuition and professional competence: Intuitive versus rational forecasting of the stock market. Vocations and Learning: Studies in Vocational and Professional Education, 1(1), 71-85. http://dx.doi.org/10.1007/s12186-007-9000-z

Heaton, J. B. (2002). Managerial Optimism and Corporate Finance. Financial Management, 31(2), 33-45. http://dx.doi.org/10.2307/3666221

Heikkilä, A. (2011). Role of Tacit Knowledge in Borrower Screening and Monitoring: Evidence from a Natural Experiment, Aalto University School of Economics and HECER, working paper.

Hertzberg, A., Liberti, J. M., \& Paravisini, D. (2010). Information and incentives inside the firm: Evidence from loan officer rotation. Journal of Finance, 65(3), 795-828. http://dx.doi.org/10.1111/j.1540-6261.2010.01553.x

Hogarth, R. M. (Ed.). (1980). Judgement and Choice: The psychology of decision. John Wiley \& Sons.

Hogarth, R. M., \& Makridakis, S. (1981). Forecasting and planning: An evaluation. Management Science, 27(2), 115-138. http://dx.doi.org/10.1287/mnsc.27.2.115

Lawrence, M. J., Edmundson, R. H., \& O'Connor, M. J. (1985). An examination of the accuracy of judgmental 
Evaluating the predictive accuracy of microloan officers' subjective judgment

extrapolation of time series. International Journal of Forecasting, 1(1), 25-35.

http://dx.doi.org/10.1016/S0169-2070(85)80068-6

Lehmann, B. (2003). Is it worth the while? The relevance of qualitative information in credit rating. Working Paper. http://dx.doi.org/10.2139/ssrn.410186

Lipshitz, R., \& Shulimovitz, N. (2007). Intuition and emotion in bank loan officers' credit decisions. Journal of Cognitive Engineering and Decision Making, 1(2), 212-233. http://dx.doi.org/10.1518/155534307X232857

List, J. A. (2003). Does market experience eliminate market anomalies?. Quarterly Journal of Economics, 118(1), 41-71. http://dx.doi.org/10.1162/00335530360535144

McCarthy, T. M., Davis, D. F., Golicic, S. L., \& Mentzer, J. T. (2006). The evolution of sales forecasting management: A 20-year longitudinal study of forecasting practices. Journal of Forecasting, 25(5), 303-324. http://dx.doi.org/10.1002/for.989

McNamara, G., \& Bromiley, P. (1997). Decision making in an organizational setting: cognitive and organizational influences on risk assessment in commercial lending. The Academy of Management Journal, 40(5), 1063-1088. http://dx.doi.org/10.2307/256927

Muradoglu, G., \& Önkal, D. (1994). An exploratory analysis of the portfolio managers' probabilistic forecasts of stock prices. Journal of Forecasting 13(7), 565- 578. http://dx.doi.org/10.1002/for.3980130702

Petersen, M. A., \& Rajan, R. G. (1994). The benefits of lending relationships: Evidence from small business data. The Journal of Finance, 49(1), 3-37. http://dx.doi.org/10.1111/j.1540-6261.1994.tb04418.x

Petersen, M. A., \& Rajan, R. G. (1995). The effect of credit market competition on lending relationships. Quarterly Journal of Economics, 110(2), 407-443. http://dx.doi.org/10.2307/2118445

Peterson, C. R., \& Beach, L. R. (1967). Man as an intuitive statistician. Psychological Bulletin, 68(1), 29-46. http://dx.doi.org/10.1037/h0024722

Ravina, E. (2008). Love \& loans: The effect of beauty and personal characteristics in credit markets. Working Paper. http://ssrn.com/abstract=1101647

Schrader, J. (2009). The competition between relationship-based microfinance and transaction lending. Working Paper. http://dx.doi.org/10.2139/ssrn.1522422

Schreiner, M. (2004). Scoring arrears at a microlender in Bolivia. Journal of Microfinance, 6(2), 65-88.

Scott, J. A. (2006). Loan officer turnover and credit availability for small firms. Journal of Small Business Management, 44(4), 544-562. http://dx.doi.org/10.1111/j.1540-627X.2006.00186.x

Shanteau, J. (1992). The psychology of experts: An alternative view. In G. Wright, \& F. Bolger (Eds.). Expert and decision support (pp. 11-21). New York. NY: Plenum. http://dx.doi.org/10.1007/978-0-585-34290-0_2

Somerville, R. A., \& Taffler, R. J. (1995). Banker judgment versus formal forecasting models: The Case of Country Risk Assessment. Journal of Banking \& Finance, 19(2), 281-297. http://dx.doi.org/10.1016/0378-4266(94)00051-4

Stein, J. C. (2002). Information production and capital allocation: decentralized versus hierarchical firms. Journal of Finance, 57(5), 1891-1921. http://dx.doi.org/10.1111/0022-1082.00483

Storey, D. (2004). Racial and gender discrimination in the micro firms Credit Market?. Small Business Economics, 23(5), 401-422. http://dx.doi.org/10.1007/s11187-004-7259-0

Taffler, R. J., \& Abassi, B. (1984). Country risk: A model for predicting debt servicing problems in developing countries. Journal of the Royal Statistical Society, 147(4), 541-568. http://dx.doi.org/10.2307/2981843

Turner, D. S. (1990). The role of judgement in macroeconomic forecasting. Journal of Forecasting, 9(4), 315-345. http://dx.doi.org/10.1002/for.3980090404

Tversky, A., \& Kahneman, D. (1979). Prospect theory: An analysis of decision under risk. Econometrica, 47(2), 263-292. http://dx.doi.org/10.2307/1914185

Uchida, H., Yamori, N., \& Udell, G. F. (2012). Loan officers and relationship lending to SMEs. Journal of Financial Intermediation, 21(1), 97-122. http://dx.doi.org/10.1016/j.jfi.2011.06.002

Wolfe, C., \& Flores, B. (1990). Judgmental adjustment of earnings forecasts. Journal of Forecasting, 9(4), 389-405. http://dx.doi.org/10.1002/for.3980090407 
Baklouti, I. \& Baccar, A. 